\title{
Relative Importance of Sectoral and Aggregate Sources of Price Changes*
}

\author{
Hiranya K. Nath ${ }^{\dagger}$
}

\begin{abstract}
This paper estimates a dynamic common factor model to assess relative importance of the aggregate and the sector-specific factors that determine changes in the prices of individual products. It also examines how aggregate price changes are affected by these factors. Two different specifications of the model are estimated: the baseline model with one aggregate factor, and a second specification with two aggregate factors. In the one factor model, the aggregate factor contributes little to the movements of changes in prices, mostly of nondurable goods whereas it seems to have important contributions to the movements of changes in prices of commodity groups mainly used as intermediate or capital goods. In the specification with two aggregate factors, the additional factor has significant effects on changes in prices of 'farm products' and 'processed foods and feeds' only. Forecast-error variance decompositions of both aggregate and disaggregate price changes suggest that sectoral factors account for most of the variability at short horizons while the contributions of the aggregate factors increase as the time horizon lengthens. The results also show that sectoral factors are not only important for relative price changes but also have significant impact on aggregate inflation. The estimated common factors have statistically significant correlations with money growth and changes in the unemployment rate.
\end{abstract}

Keywords: Dynamic Common Factor Model; Aggregate Factors; Sector-specific Factors; Forecast-error Variance Decomposition

JEL classification: E31; E32

\footnotetext{
* The author is grateful to Nathan S. Balke for many helpful discussions. The author would also like to thank Pinaki Chakraborty, Tricia Coxwell, Tom Fomby, Thomas Osang, Mark Wynne, and the audience at the $35^{\text {th }}$ Annual Meetings of the Canadian Economic Association held in Montreal, and at the $71^{\text {st }}$ Annual Conference of the Southern Economic Association held in Tampa, and the seminar participants at the Southern Methodist University and at the Sam Houston State University for their comments, and Jakovs Itkins for his help with the programs.

${ }^{\dagger}$ Department of Economics and International Business, Sam Houston State University, Huntsville, TX 77341-2118, USA; Phone: 936294 4760; Fax: 936294 3488; E-mail: eco_hkn@shsu.edu
} 


\section{Introduction}

The existence of a positive correlation between inflation and relative price variability is one empirical regularity that has evoked immense interests among the economists in the last quarter of the $20^{\text {th }}$ century. Although this was observed by Mills (1927) and Graham (1930) much earlier, it received little attention until the mid-seventies when Vining and Elwertowski (1976) re-examined this relationship. Interestingly, the publication of their work coincided with the aftermath of the high and extremely volatile inflation of the early 70s, which many economists blamed on so-called 'supply shocks' ${ }^{1}$ (for example, see Blinder, 1982). These supply shocks were typically associated with increases in the relative prices, such as food and energy prices. The debates and discussions of that period brought to the fore the importance of relative price changes. One stream of the literature that attempts to explain the relationship between inflation and relative price variability focuses on the sources of relative price changes. For example, using a multisectoral supply-and-demand model that fits the misperceptions model framework of Lucas (1973), Parks (1978) shows that changes in real income and unanticipated inflation explain a large part of relative price variance. Hercowitz (1981) further extends the misperceptions models of Lucas (1973) and Barro (1976) to show that unanticipated money growth is responsible for the rise in relative price dispersion, which is inflationary. More recently, Ball and Mankiw (1995) argue that the existence of menu costs faced by firms in adjusting prices gives rise to relative price changes, which in turn leads to aggregate inflation. Using a multisector flexible price general equilibrium model, Balke and Wynne (2000), on the other hand, argue that sectoral technology shocks can

\footnotetext{
${ }^{1}$ One notable exception is Barsky and Kilian (2002) who argue that Fed's expansionary monetary policy bears much of the blame for the stagflation of the 70s.
} 
lead to relative price changes and aggregate inflation. In a recent study that examines the relationship between sectoral price changes and output growth in the U.S., Balke and Nath (2001) further argue that sector-specific factors such as sectoral technology or sectoral autonomous expenditures, change supply and demand conditions across sectors in such a way that they may cause relative prices to change and these changes can have significant impact on the aggregate price changes.

Among the purely empirical works, Fischer (1981) uses quarterly data for the U.S. from 1948 to 1980 , to show that both aggregate monetary shocks and sectoral shocks such as food and energy shocks could be important sources of relative price variability and aggregate inflation. Loungani and Swagel (1995) use a panel VAR methodology applied to data for 13 OECD countries and reach similar conclusions. Debelle and Lamont (1997), on the other hand, use panel data from major cities in the U.S. to show the robustness of the relationship between inflation and price variability across regions and times. Their results show that this relationship is at least partly explained by non-monetary disaggregate shocks.

This literature, of which we have discussed a select few, makes two points. First, the factors affecting individual price changes could be of two types: aggregate factors that affect all prices in the economy and sector-specific factors that affect a single price. The underlying disturbances to these factors drive the fluctuations in individual product prices, which may have important consequences for the distribution of relative price changes. Second, a section of this literature also indicates that sector-specific factors may have significant impact on aggregate price changes. Note that the classical view on this issue is that sectoral developments lead to changes in relative prices but do not affect the 
aggregate price level. According to this view, a rise in price in one market would be accommodated by decline of prices in other markets for a given stock of money (see Friedman, 1975).

The main purpose of this paper is to assess relative importance of the aggregate and the sector-specific factors that affect individual price changes. It also examines whether the sector-specific factors have any significant impact on aggregate price changes. We use a dynamic common factor model analogous to that of Stock and Watson (1991), to calculate contributions of aggregate and sectoral factors to price changes for a broad cross-section of prices. The advantage of this model is that we do not have to subscribe to any particular theory of price changes. Since there is no unique set of factors affecting price changes that the economists have agreed upon, and our goal is to examine the importance of two broad categories of factors, namely, aggregate factors and sectorspecific factors, this methodology seems to be appropriate to use. In a nutshell, a dynamic common factor model picks the effects of the aggregate factor(s) from the comovements of different prices along with its (their) underlying dynamics. This kind of model has been used in the price behavior literature, but in a different context. For example, Bryan and Cecchetti (1993) use similar model to decompose individual price changes into a common inflation component (core inflation) and an idiosyncratic relative price change component. In this paper, on the other hand, we decompose individual price changes into a component that reflects the effects of aggregate factor(s), and a component that reflects the effects of an idiosyncratic factor under a very general assumption that relative price changes may result from both aggregate and disaggregate factors. Thus this analysis 
encompasses a broad spectrum of possible theoretical explanations of relative price changes.

We report detailed parameter estimates for two specifications of the model: the baseline model with one common (aggregate) factor and the second with two common factors. The aim of the second specification is to evaluate the possibility of more than one aggregate factor that may affect price changes. In fact, we find evidence in support of more than one aggregate factor. Our results show that in most cases aggregate factors contribute little to the movements of price changes particularly for nondurable goods. Forecast-error variance decompositions of both aggregate and disaggregate price changes suggest that sectoral factors account for most of the variability at short forecast horizons while the contributions of the aggregate factor(s) increase as the time horizon lengthens. Sector-specific factors have significant impact on aggregate inflation as well. The estimated aggregate factors seem to reflect money growth and changes in the unemployment rate.

The rest of the paper is organized as follows. Section II discusses some basic summary statistics of price changes and the principal component analysis results that shed lights on the sources of individual price changes. Section III describes a dynamic common factor model of price changes. In section IV, we discuss the data and present the main empirical results. Section V examines if the empirical results support the view that sector-specific factors have significant impact on aggregate inflation. In section VI, we make an attempt to give economic interpretation of the estimated common factors. Section VII summarizes this paper. 


\section{What do we learn about sources of price changes from basic statistics?}

In this section, we present some basic summary statistics of price changes and conduct principal component analysis to shed lights on the nature of various factors that might cause changes in the prices of individual products. The aim is to provide some intuition as to the sources of price changes, and to explain the motivation behind our analysis in subsequent sections.

We use monthly data on producer price index ${ }^{2}$ (PPI hereafter) for 15 major commodity groups, for a period from January 1947 to January 2000. These are 2-digit commodity groups covering agriculture, forestry, mining and manufacturing - as defined by the Bureau of Labor Statistics (BLS). The data have been extracted from the ftp site for Producer Price Index maintained by the BLS.

Table 1 presents some of the summary statistics of monthly price changes for the 15 commodity groups. Price changes are calculated as the differences in natural logarithms of monthly PPIs. In column 1, we report the average price changes for each of the commodity groups over the sample period. Column 2 presents the standard deviation of monthly price changes, and in column 3 we present the mean pair-wise crosscorrelations averaged over the commodity groups, for each commodity group. As we can see from column 3, for more than half of the commodity groups, there is a fair amount of cross-sectional correlation (i.e. comovement). This comovement can be interpreted as

\footnotetext{
${ }^{2}$ Although the Consumer Price Index (CPI) or the Personal Consumption Expenditure (PCE) Implicit Deflator has broader coverage of both goods and services - as opposed to PPI that includes goods only and are more important from the monetary policy perspective, the reasons for using PPI in this paper are two-fold: first, to include the prices of capital goods which are not covered in previous studies (for example, Bryan and Cecchetti,1993) that consider consumer prices only. Secondly, previous research (Balke and Nath, 2001) indicates that prices of different types of goods such as consumption goods, capital goods etc., have interestingly different dynamics in terms of the effects of aggregate and sectoral shocks on price changes.
} 
evidence of a common disturbance. It is interesting to note that except for 'transportation equipment' and 'miscellaneous products', commodity groups having smaller average pair-wise correlations, also have larger standard deviation of price changes (see column 2). For these commodity groups sectoral disturbances may be more important.

However, these statistics would not tell us whether the aggregate disturbance comes from a single factor or more than one such factor. We therefore resort to principal component analysis. As we can see from Table 2, the contributions of principal components vary across commodity groups. The contributions of the two largest components are highly asymmetric across commodity groups. In comparison, however, the third and the fourth component have somewhat uniform contributions across a large number of commodity groups. This analysis suggests that there could be more than one aggregate factor that affects price changes. Also, some of the price changes may be driven by sector-specific factors. However, this simple analysis will not capture the underlying dynamics of aggregate and sector-specific factors. We now, therefore, turn to a much richer class of models: dynamic common factor model.

\section{A dynamic common factor model for price changes}

Consider the following model in which a change in the individual price is assumed to be affected by one or more aggregate common factor and a sector-specific factor which we will also refer to as 'idiosyncratic factor'. These factors are unobserved and are assumed to have linear stochastic structures. Thus, one can write a model for price change of the following form:

$$
\mathrm{p}_{\mathrm{it}}=\alpha_{\mathrm{i}}+\gamma_{\mathrm{i}} \mathrm{C}_{\mathrm{t}}+\mathrm{u}_{\mathrm{it}}
$$


where $\mathrm{p}_{i t}$ is the change in price of good $\mathrm{i}$ in period $\mathrm{t}, \mathrm{C}_{\mathrm{t}}$ is an $\mathrm{m} \times 1$ vector of the aggregate common factors in period $t$ and $\mathrm{u}_{\mathrm{it}}$ is the idiosyncratic factor affecting good $\mathrm{i}$ in period t, where $\mathrm{i}=1,2, \ldots . \mathrm{n} . \gamma_{\mathrm{i}}$ is a $1 \times \mathrm{m}$ vector of parameters to be estimated. Note that these variables are included in the model in terms of changes in order to formulate the model in stationary form. $\mathrm{C}_{\mathrm{t}}$ and $\mathrm{u}_{\mathrm{it}}$ are assumed to be generated by the following $\mathrm{AR}$ processes:

$$
\begin{aligned}
& \mathrm{C}_{\mathrm{t}}=\sum_{\mathrm{j}=1}^{\mathrm{p}} \varphi_{\mathrm{j}} \mathrm{C}_{\mathrm{t}-\mathrm{j}}+\eta_{\mathrm{t}} \\
& \mathrm{u}_{\mathrm{it}}=\sum_{\mathrm{k}=1}^{\mathrm{q}} \delta_{\mathrm{ik}} \mathrm{u}_{\mathrm{it}-\mathrm{k}}+\varepsilon_{\mathrm{it}}
\end{aligned}
$$

Equation (3) can be written as:

$$
\mathrm{u}_{\mathrm{it}}=\left(1-\delta_{\mathrm{i}}(\mathrm{L})\right)^{-1} \varepsilon_{\mathrm{it}}
$$

where $\delta_{\mathrm{i}}(\mathrm{L})$ is a scalar lag polynomial of order q . Substitution into equation (1) and algebraic manipulation yield:

$$
\mathrm{p}_{\mathrm{it}}=\beta_{\mathrm{i}}+\delta_{\mathrm{i}}(\mathrm{L}) \mathrm{p}_{\mathrm{it}}+\left(1-\delta_{\mathrm{i}}(\mathrm{L})\right) \gamma_{\mathrm{i}} \mathrm{C}_{\mathrm{t}}+\varepsilon_{\mathrm{it}}
$$

where $\beta_{\mathrm{i}}=\alpha_{\mathrm{i}}\left(1-\delta_{\mathrm{i}}(\mathrm{L})\right)$. We can write this model in state space form. The observation equation (5) in vector and matrix notation can be written as:

$$
\mathrm{Y}_{\mathrm{t}}=\mathrm{AX}_{\mathrm{t}}+\mathrm{HS}_{\mathrm{t}}+\mathrm{W}_{\mathrm{t}}
$$

where

$$
\begin{aligned}
& Y_{t}=\left(p_{1 t}, p_{2 t}, \ldots \ldots, p_{n t}\right)^{\prime}, \\
& A=\left(\begin{array}{cccccccc}
\beta_{1} & \delta_{11} & \cdots & 0 & \delta_{1 q} & \cdots & 0 \\
\vdots & \vdots & \ddots & \vdots & \ddots & \vdots & \ddots & \vdots \\
\beta_{n} & 0 & \cdots & \delta_{n 1} & & 0 & \cdots & \delta_{n q}
\end{array}\right)
\end{aligned}
$$




$$
\begin{aligned}
& X_{t}=\left(1, Y_{t-1}^{\prime}, \cdots, Y_{t-q}^{\prime}\right)^{\prime} \\
& \mathrm{H}=\left(\gamma_{1} \cdots \gamma_{\mathrm{m}}-\lambda_{1,1} \cdots-\lambda_{1, \mathrm{~m}} \cdots-\lambda_{\max (\mathrm{p}-1, \mathrm{q}), 1} \cdots-\lambda_{\max (\mathrm{p}-1, \mathrm{q}), \mathrm{m}}\right)
\end{aligned}
$$

where

$$
\gamma_{\mathrm{k}}=\left(\begin{array}{c}
\gamma_{1 \mathrm{k}} \\
\vdots \\
\gamma_{\mathrm{nk}}
\end{array}\right), \lambda_{\mathrm{j}, \mathrm{k}}=\left(\begin{array}{ccc}
\delta_{1 \mathrm{j}} & \cdots & 0 \\
\vdots & \ddots & \vdots \\
0 & \cdots & \delta_{\mathrm{nj}}
\end{array}\right)\left(\begin{array}{c}
\gamma_{1 \mathrm{k}} \\
\vdots \\
\gamma_{\mathrm{nk}}
\end{array}\right) \text { for } \mathrm{j}=1,2, \ldots \ldots, \mathrm{q}
$$$$
\text { and } \lambda_{\mathrm{j}, \mathrm{k}}=\left(\begin{array}{c}
0 \\
\vdots \\
0
\end{array}\right) \text { for } \mathrm{j}=\mathrm{q}+1, \ldots \ldots, \mathrm{p}-1 \text { if } \mathrm{p}-1>\mathrm{q} \text { and } \mathrm{k}=1,2, \ldots \mathrm{m}
$$$$
\mathrm{S}_{\mathrm{t}}=\left(\mathrm{C}_{1, \mathrm{t}}, \ldots \mathrm{C}_{\mathrm{m}, \mathrm{t}}, \mathrm{C}_{1, \mathrm{t}-1}, \ldots \mathrm{C}_{\mathrm{m}, \mathrm{t}-1}, \ldots \ldots \ldots, \mathrm{C}_{1, \mathrm{t}-(\mathrm{p}-1), \ldots} \mathrm{C}_{\mathrm{m}, \mathrm{t}-(\mathrm{p}-1)}\right)^{\prime}
$$

and

$$
\mathrm{W}_{\mathrm{t}}=\left(\varepsilon_{1 \mathrm{t}}, \varepsilon_{2 \mathrm{t}}, \ldots \ldots, \varepsilon_{\mathrm{nt}}\right)^{\prime} \sim \mathrm{N}(0, \mathrm{R})
$$

$\mathrm{R}$ is a diagonal matrix. This is an implication of the assumption that the idiosyncratic factors are orthogonal to each other. In other words, they are uncorrelated to each other at all lags and leads. We also assume that they are uncorrelated with the common factor(s), and that the common factors themselves are orthogonal to each other.

The state transition equation for the state-space model can be written as follows:

$$
\mathrm{S}_{\mathrm{t}}=\mathrm{FS}_{\mathrm{t}-1}+\mathrm{V}_{\mathrm{t}}
$$

where

$$
\mathrm{F}=\left(\begin{array}{cccc}
\phi_{1} & \cdots & \cdots & \phi_{\mathrm{p}} \\
& \mathrm{I}_{\mathrm{m}(\mathrm{p}-1) \mathrm{xm}(\mathrm{p}-1)} & & 0_{\mathrm{m}(\mathrm{p}-1) \mathrm{xm}}
\end{array}\right)
$$

where

$$
\begin{aligned}
\phi_{l} & =\left(\begin{array}{ccc}
\varphi_{1 l} & \cdots & 0 \\
\vdots & \ddots & \vdots \\
0 & \cdots & \varphi_{\mathrm{ml}}
\end{array}\right) \quad \text { for } l=1,2, \ldots \ldots, \mathrm{p} \\
\mathrm{V}_{\mathrm{t}} & =\left(\eta_{1 \mathrm{t}}, \ldots \eta_{\mathrm{mt}}, 0_{\mathrm{m}(\mathrm{p}-1) \mathrm{X} 1}\right)^{\prime}
\end{aligned}
$$




$$
\mathrm{Q}=\mathrm{E}\left(\mathrm{V}_{\mathrm{t}} \mathrm{V}_{\mathrm{t}}^{\prime}\right)=\left(\begin{array}{cccc}
\sigma_{\eta_{1}} & & 0 & 0_{1 \times \mathrm{m}(\mathrm{p}-1)} \\
& \ddots & & 0_{1 \times \mathrm{m}(\mathrm{p}-1)} \\
0 & & \sigma_{\eta_{\mathrm{m}}} & 0_{\mathrm{m}(\mathrm{p}-1) \times \mathrm{m}(\mathrm{p}-1)} \\
0_{\mathrm{m}(\mathrm{p}-1) \times 1} & \cdots & 0_{\mathrm{m}(\mathrm{p}-1) \times 1} & 0_{\mathrm{m}}
\end{array}\right)
$$

We impose additional identifying restrictions: $\sigma_{\eta \mathrm{k}}=1$ where $\mathrm{k}=1,2, \ldots \ldots \mathrm{m}$

\section{Empirical results}

For the estimation of the model, we use monthly data on the PPI for 15 commodity groups for a period from 1950:1 to 2000:1, a sub-sample of the data set that we have already discussed in section 2 . We take first log differences of prices to be the dependent variables ${ }^{3}$ in the observation equations. We de-mean the data so that we do not have to estimate the intercept terms in the observation equations.

First, one has to decide how many aggregate common factors to include in the model and what lags to choose for the aggregate and sector-specific factors. We estimate several specifications of the model with different numbers of common factors and with various lags. Using information criteria, we find that for each specification with a different number of common factors, the appropriate lags are two ${ }^{4}$. That is, $\mathrm{p}=2$ and $\mathrm{q}=$ 2. It may be noted that Bryan and Cecchetti (1993) use this specification of lag lengths for their estimation of dynamic common factor model of price changes. However,

\footnotetext{
${ }^{3}$ In order to verify stationarity of these log-differenced price series, we conduct Augmented Dickey-Fuller Test for each of them separately. For each series, the null hypothesis of a unit root is rejected at 1 percent significance level. Since we are using monthly data, in the test equation we include the augmented terms with a maximum lag of 12 and then based on the information criteria we select the appropriate lag lengths. There is no uniformity of the lag lengths and they also vary according to whether we use Akaike Information Criterion (AIC) or Schwarz Criterion (SC). Interested reader can obtain detailed test results from the author.

${ }^{4}$ For example, for the baseline model with $\mathrm{p}=1$ and $\mathrm{q}=1$, AIC $=27.99$; for $\mathrm{p}=1$ and $\mathrm{q}=2$, AIC $=36.38$; for $\mathrm{p}=2$ and $\mathrm{q}=1, \mathrm{AIC}=1.25$; for $\mathrm{p}=2$ and $\mathrm{q}=2$, AIC $=1.03$; for $\mathrm{p}=3$ and $\mathrm{q}=2$, AIC $=6.64$; and for $\mathrm{p}$ $=3$ and $q=3$, AIC $=5.34$.
} 
deciding the number of common factor is more difficult. As we can see from Panel A of Table 3, as the number of common factor increases the values of AIC get smaller indicating that more than one aggregate common factor give better fit of the model. Schwarz Criterion (SC), on the other hand, indicates that the two-factor model is the best because it has the smallest value of SC. We also use a sequential likelihood ratio test procedure to examine the statistical significance of the additional common factors ${ }^{5}$. The results are reported in panel B of Table 3. The test results suggest that additional factors are statistically significant. However, we do not report the parameter estimates for models with more than two factors because the additional common factors have limited effects on individual price changes in the sense that they have relatively larger effects on the prices of a few commodity groups and have negligible effects on the prices of others. Thus they do not have the true character of an aggregate factor. We would call the one factor model the baseline model.

The parameters of the models are first estimated by using the EM algorithm and these parameter estimates are taken as the initial values for the maximum likelihood estimation $^{6}$ of the model. The EM algorithm iterates back and forth between the estimation step that constructs data on the unobserved state variables conditional on observed data and some specified initial values for the parameters using the Kalman filter and smoother, and the maximization step that calculates the maximum likelihood estimates of the parameters conditional on the observed and constructed data, until convergence of the parameter estimates (with a parameter tolerance of 0.001) is achieved.

\footnotetext{
${ }^{5}$ Singleton (1980) uses a sequential chi-squared test procedure to determine the number of common factor. Norrbin and Schlagenhauf (1990), on the other hand, use likelihood ratio test to examine the importance of different sets of factors.

${ }^{6}$ We use multidimentional unconstrained minimization algorithm (Nelder-Mead) for the ML estimation.
} 
The recursion for the Kalman filter begins with the unconditional mean of the state vector, i.e. a vector of 0 s in this case. For the model with one common factor, 63 parameters are estimated whereas for the model with two common factors, a total of 81 parameters are estimated.

\section{Parameter estimates}

Table 4 presents estimates of the autoregressive parameters of the state transition equation for the two models. The estimated AR coefficients for the baseline model indicate that innovations in this factor are highly persistent and have relatively larger and statistically significant effects at the first lag. For the two-factor model innovations in the second common factor are not persistent and the estimated AR coefficients are not statistically significant.

In Table 5, we present the estimates of the parameters of the observation equations. Panel A presents the results for the baseline model while in panel B we present the estimates for the two factor model. For both models, estimated $\delta$ s suggest that price changes are fairly persistent for 'textile products and apparel', 'hides, skins, leather and related products', 'fuels and related products and power', 'chemicals and allied products', 'rubber and plastic products', 'lumber and wood products', 'metals and metal products', 'machinery and equipment' and 'nonmetallic mineral products'.

The contemporaneous effects of the common factor on price changes in the baseline model, and of the first factor in the two factor model - represented by $\gamma_{\mathrm{i}} \mathrm{s}$ and $\gamma_{\mathrm{i} 1}$ s respectively - are statistically significant for 13 commodity groups at least at the 5 percent significance level. It is interesting to note that in the two-factor model the second common factor has large and statistically significant contemporaneous effects on changes 
in prices of 'farm products' and 'processed foods and feeds' only. It has negligible effects on the changes in prices of other products. The estimated variances of the error terms in the observation equations are reported in the last column of Table 5. In the one factor model, prices of farm products, processed food, fuel, and lumber and wood products exhibit relatively high volatility. A comparison between the variance estimates for the two models indicate that the second common factor captures some of the volatility in price changes for farm products and processed food.

It is difficult to make conclusive comments on the basis of the parameter estimates of the model. Therefore, we plot the contributions of the common factor(s) to price changes for all 15 different commodities against actual price changes (see Figure 1 and Figure 2). The contributions of the common factor(s) to the values of the observation variables are estimated by $\mathrm{Y}_{\text {conc }}=\mathrm{HS}_{\mathrm{t} \mid \mathrm{T}}$ where $\mathrm{S}_{\mathrm{t} \mid \mathrm{T}}$ is the smoothed estimate of the state vector obtained from the models. The following observations can be made.

i) In the one factor model, the aggregate factor contributes little to the movements of price changes for 'farm products', 'processed foods and feeds', 'textile products and apparel', 'hides, skins, leather and related products', 'fuels and related products and power', 'lumber and wood products', 'transportation equipment' and 'miscellaneous products'. Note that except the last two commodity groups, these are nondurable goods.

ii) As one can see from the figures, the aggregate factor seems to have important contributions to the movements of changes in prices of 'chemicals and allied products', 'pulp, paper and related products', 'nonmetallic mineral products' 'machinery and equipment' and 'furniture and household durable goods'. Note 
that the first three commodity groups are mostly used as intermediate goods. On the other hand, 'machinery and equipment' is an important capital goods category $^{7}$.

iii) Once we introduce the second common factor, the most striking change in the results is that now the movements in the common factors reflect most of the behavior of price changes for 'farm products' and 'processed foods and feeds'. Thus the second common factor is more like a specific factor, only with effects in more than one sector.

\section{Relative importance of sectoral and aggregate factors}

In this sub-section, we assess relative importance of the sectoral and aggregate factors in the determination of changes in individual prices from a dynamic point of view. We adopt a methodology ${ }^{8}$ that provides us with decomposition of forecast error variances at various time horizons. We first derive a moving average representation of the state space model (6)-(7). This representation facilitates decomposition of forecast error variances into a component that emanates from variability in the aggregate factor(s) and one that results from variability in the sectoral factors. Equations (6) and (7) can be written as follows:

$$
\begin{aligned}
& (\mathrm{I}-\mathrm{A}(\mathrm{L})) \mathrm{Y}_{\mathrm{t}}=\mathrm{HS}_{\mathrm{t}}+\mathrm{W}_{\mathrm{t}}{ }^{9} \\
& (\mathrm{I}-\mathrm{FL}) \mathrm{S}_{\mathrm{t}}=\mathrm{V}_{\mathrm{t}}
\end{aligned}
$$

Note that $\mathrm{A}(\mathrm{L})$ is a lag polynomial matrix and

\footnotetext{
${ }^{7}$ On the basis of BLS' classification scheme it is not possible to categorize a commodity group as entirely belonging to intermediate or capital goods category.

${ }^{8}$ Similar methodology is used by Norrbin and Schlagenhauf (1990)

${ }^{9}$ Since we use demeaned values of $\mathrm{Y}$ variables to estimate the model, we can ignore the intercept terms in the observation equation.
} 


$$
A(L)=A_{1} L+A_{2} L^{2}
$$

where

$$
\mathrm{A}_{\mathrm{k}}=\left(\begin{array}{ccc}
\delta_{1 \mathrm{k}} & \cdots & 0 \\
\vdots & \ddots & \vdots \\
0 & \cdots & \delta_{\mathrm{nk}}
\end{array}\right), \quad \mathrm{k}=1,2
$$

Algebraic manipulation and substitution yield:

$$
\begin{aligned}
Y_{t} & =\left(I-A_{1} L-A_{2} L^{2}\right)^{-1} H(I-F L)^{-1} V_{t}+\left(I-A_{1} L-A_{2} L^{2}\right)^{-1} W_{t} \\
& =\left(\sum_{i=0}^{\infty} \Phi_{i} L^{i}\right) H\left(I+\sum_{i=1}^{\infty} F^{i} L^{i}\right) V_{t}+\left(\sum_{i=0}^{\infty} \Phi_{i} L^{i}\right) W_{t}
\end{aligned}
$$

where

$$
\begin{array}{ll}
\Phi_{0}=\mathrm{I} & \text { where } \mathrm{I} \text { is an } \mathrm{n} \times \mathrm{n} \text { identity matrix } \\
\Phi_{1}=\mathrm{A}_{1} \Phi_{0} & \\
\Phi_{\mathrm{i}}=\mathrm{A}_{1} \Phi_{\mathrm{i}-1}+\mathrm{A}_{2} \Phi_{\mathrm{i}-2}, & \mathrm{i}=2,3, \ldots \ldots
\end{array}
$$

The moving average representation of $\mathrm{Y}_{\mathrm{t}}$ is

$$
\begin{array}{r}
\mathrm{Y}_{\mathrm{t}}=\Theta_{0} \mathrm{~V}_{\mathrm{t}}+\Theta_{1} \mathrm{~V}_{\mathrm{t}-1}+\Theta_{2} \mathrm{~V}_{\mathrm{t}-2}+\Theta_{3} \mathrm{~V}_{\mathrm{t}-3}+\ldots . . \\
\mathrm{W}_{\mathrm{t}}+\Phi_{1} \mathrm{~W}_{\mathrm{t}-1}+\Phi_{2} \mathrm{~W}_{\mathrm{t}-2}+\Phi_{3} \mathrm{~W}_{\mathrm{t}-3}+\ldots \ldots
\end{array}
$$

where

$$
\begin{aligned}
& \Theta_{0}=\Phi_{0} H, \\
& \Theta_{j}=\Phi_{j} H+\Theta_{j-1} F, \quad j=1,2,3, \ldots \ldots
\end{aligned}
$$

This representation can now be used to derive a meaningful decomposition of the variance of price changes by calculating the variance of the forecast error at various time horizons. Let us specify the set of information available at time t as follows:

$$
\Omega_{\mathrm{t}} \equiv\left\{\mathrm{W}_{\mathrm{t}}, \mathrm{W}_{\mathrm{t}-1}, \ldots \ldots . ., \mathrm{V}_{\mathrm{t}}, \mathrm{V}_{\mathrm{t}-1}, \ldots \ldots\right\}
$$

Then the variance of k-period-ahead forecast error of price changes can be written as: 


$$
\begin{array}{r}
\operatorname{var}\left(\mathrm{Y}_{\mathrm{t}+\mathrm{k}} \mid \Omega_{\mathrm{t}}\right) \equiv \mathrm{E}\left\{\left[\mathrm{Y}_{\mathrm{t}+\mathrm{k}}-\mathrm{E}\left(\mathrm{Y}_{\mathrm{t}+\mathrm{k}} \mid \Omega_{\mathrm{t}}\right)\right]\left[\mathrm{Y}_{\mathrm{t}+\mathrm{k}}-\mathrm{E}\left(\mathrm{Y}_{\mathrm{t}+\mathrm{k}} \mid \Omega_{\mathrm{t}}\right)\right]\right\} \\
=\Theta_{0} \mathrm{Q}_{0}^{\prime}{ }^{\prime}+\ldots \ldots . .+\Theta_{\mathrm{k}} \mathrm{Q}_{\mathrm{k}}^{\prime}{ }^{\prime}+\mathrm{R}+\Phi_{1} \mathrm{R} \Phi_{1}^{\prime}+\ldots .+\Phi_{\mathrm{k}} \mathrm{R} \Phi_{\mathrm{k}}{ }^{\prime}(12)
\end{array}
$$

Because of the assumptions of orthogonality between common and idiosyncratic factors and of $\mathrm{W}_{\mathrm{t}}$ and $\mathrm{V}_{\mathrm{t}}$ being white noise, all the covariance terms disappear. It is clear from equation (12) that the variances of forecast error of price changes can be decomposed into two components: the first component originates in the common factor(s) and the second arises from the sectoral or idiosyncratic factor.

Table 6 presents variance decompositions for 15 different prices at horizons 0,1 year and 5 years. From these results we can draw the following conclusions. First, at shorter forecast horizons, aggregate factor(s) accounts for only a small part of the variability of price changes for different goods, though the magnitudes vary. However, they gain importance at longer horizons. Second, aggregate factors account for more than 10 percent of variability in the price changes for chemicals, pulp and paper products, metals and metal products, machinery and equipment, furniture and household durable, and nonmetallic mineral products at horizon 0. Finally, in the two-factor model, the second aggregate factor explains a large part of the variances of changes in prices of farm products and processed food. For other commodity groups its contributions are negligible.

\section{Are sector-specific factors important for aggregate inflation?}

In this section, we first define aggregate (demeaned) inflation in period $\mathrm{t}$ as ${ }^{10}$

\footnotetext{
${ }^{10}$ Note that this is not how aggregate inflation is calculated. An aggregate index is constructed by applying these weights to individual commodity prices (at level and not at log differences). Then percentage changes are calculated. However, since we calculate aggregate inflation from the real data using the same definition as from the estimated commodity price changes it makes actual and estimated aggregate inflation comparable. Also see Bryan and Cecchetti (1993)
} 


$$
\Pi_{\mathrm{t}}=\Psi \mathrm{Y}_{\mathrm{t}}
$$

where $\Psi$ is a $1 \times 15$ vector of weights as calculated by BLS on the basis of 1992 values of shipments of commodities. The variance of aggregate inflation is given by

$$
\operatorname{var}(\Pi)=\Psi \operatorname{var}(\mathrm{Y}) \Psi^{\prime}
$$

We can now use the relationship (12) to obtain forecast error variance decomposition for aggregate inflation at various time horizons.

We carry out two exercises. First, we calculate variance decomposition for a measure of aggregate inflation that includes all 15 commodity groups. Then we exclude 'farm products', 'processed foods and feeds' and 'fuels and related products'. Food and energy sectors are often blamed for high volatility of aggregate inflation. In this exercise, we want to examine how the relative importance of aggregate factors vis-àvis idiosyncratic factors changes when we exclude the variances of these volatile sectors from the measurement of the forecast-error variances of aggregate inflation. We set the weights for these three commodity groups equal to 0 and re-scale the weights for other commodity groups. Panel A and Panel B of Table 7 present forecast-error variance decompositions at the following time horizons: $0-12$ months and 2,3,4 and 5 years for these two experiments respectively. As we can see from Panel A, in the baseline model, sectoral factors account for most of the variances at all horizons whereas in the two factor model, they account for at least about half of the variances. The contribution of aggregate factor(s) increases over time. With one common factor, the contribution rises from a mere 2.59 percent in period 0 to about 25 percent in year 5 . With two common factors, on the other hand, about 22 percent of the variance can be attributed to the aggregate factors in 
period 0 and it increases to about 50 percent in year 5 . Note that most increases occur in the first year.

When we exclude food and energy the contribution of the common factor increases from about 10 percent in period 0 to 61 percent in year 5 for the one factor model. On the other hand, for the two-factor model the contribution increases from about 12 percent in period 0 to about 61 percent in year 5 . The contributions of the aggregate factor in the baseline model and the combined contributions of the aggregate factors in the two factor model are almost the same at all horizons. The result of this exercise reinforces our earlier conclusion that the second common factor does not have the true character of an aggregate factor. It also illustrates the importance of changes in relative prices of food and energy as the supply shocks responsible for high and extremely volatile inflationary episodes such as those of the 70s.

\section{Exploring the economics behind the estimated common factors}

The aggregate common factors that we estimate in these models do not have any a-priori interpretation. In this section, we will examine if the estimated common factors mimic the behavior of some of the traditional candidates of aggregate factors, such as changes in money stock, unemployment and government expenditures.

In order to verify if the estimated common factor(s) reflects changes in the money stock, which has traditionally been described as the most important aggregate factor that causes price changes, we calculate the correlation coefficients between the estimated common factor(s) and changes in M1, M2, $3^{11}$ and the monetary base (MB). Note that

\footnotetext{
${ }^{11}$ It is well known that all these three broad measures of the money stock have a significant endogenous component, and the extent to which any of them reflects changes in exogenous monetary policy is controversial. Therefore, we use MB as an alternative measure.
} 
monthly data on M1, M2 and M3 are obtained for a period from January 1959 to January 2000 from the Federal Reserve Bulletin and monthly data on MB for the same period are obtained from the Monetary trends published by the Federal Reserve Bank of St. Louis. These coefficients are reported in Table 8. The common factor estimated from the one factor model, has statistically significant correlations with changes in M1, in M3 and in MB. Similarly, the first common factor estimated from the two-factor model has statistically significant correlations only with changes in M3 and in MB.

Now we examine if any of the estimated common factors reflects changes in unemployment. Changes in unemployment affects price changes through the Phillips curve relationship that implies a short-run tradeoff between unemployment and inflation. When the unemployment rate increases it implies a decline in aggregate demand. That is, the demand for commodities decreases. When demand decreases, both price and output decrease in the short-run. We obtain monthly data on the unemployment rate from the Bureau of Labor Statistics for the period from January 1959 to January 2000 and calculate the correlation coefficients between changes in the unemployment rate and the estimated common factors for the same sample period. We find that the correlations with the estimated common factor of the one-factor model and the first common factor of the two-factor model are statistically significant at $1 \%$ level.

A change in government purchases could be another aggregate factor that drives price changes. Do the estimated common factors reflect changes in government purchases? We obtain monthly data ${ }^{12}$ on aggregate government purchases for the sample

\footnotetext{
${ }^{12}$ Note that government purchases data are available at quarterly frequency. They are converted to monthly frequency using a method that assumes linear distribution of government purchases, provided by the DRIPro database from where the data have been extracted.
} 
period from January 1959 to January 2000 from the Bureau of Economic Analysis, take first differences of their logarithmic values and calculate their correlation with the estimated common factors for the same sample period. The correlation coefficients are negative. Only the correlation with the second factor in the two-factor model is statistically significant at 5\% level. Since for most commodity groups, government purchases constitute only a small fraction of the final demand changes in them must have negligible impact on the prices of their products.

\section{Summary}

This paper estimates a dynamic common factor model of price changes to assess relative importance of the sectoral and aggregate factors in the determination of price changes. In the baseline specification with one common factor, the aggregate factor contributes little to the movements of price changes mostly for nondurable goods whereas it seems to have important contributions to the movements of changes in prices of commodity groups mainly used as intermediate or capital goods. In the specification with two common factors, although the inclusion of the second factor is statistically significant, it is important for changes in prices of 'farm products' and 'processed foods and feeds' only. Forecast error variance decompositions of both aggregate and disaggregate price changes illustrate that the contributions of aggregate factors to the variance of price changes increase over time. The results of the paper also indicate that sector-specific factors not only drive relative price changes but also have significant impact on aggregate inflation. Evidence suggests that the estimated common factors reflect money growth or changes in the unemployment rate to some extent. 


\section{Table 1}

Summary Statistics of Price Changes

Monthly: February 1947 - January 2000

\begin{tabular}{|l||c|c|c|}
\hline Commodity Groups & Mean & $\begin{array}{c}\text { Standard } \\
\text { Deviation } \\
(1)\end{array}$ & $\begin{array}{c}\text { Average } \\
\text { Pairwise } \\
\text { Correlation } \\
(3)\end{array}$ \\
\hline Farm products & 0.13 & 2.20 & $\begin{array}{c}0.14 \\
(0.19)\end{array}$ \\
\hline Processed foods and feeds & 0.22 & 1.19 & $\begin{array}{c}0.20 \\
(0.18)\end{array}$ \\
\hline Textile products and apparel & 0.14 & 0.53 & $\begin{array}{c}0.32 \\
(0.14)\end{array}$ \\
\hline Hides, skins, leather & 0.26 & 1.17 & $\begin{array}{c}0.16 \\
(0.09)\end{array}$ \\
\hline Fuels and related products & 0.37 & 2.01 & $\begin{array}{c}0.16 \\
(0.11)\end{array}$ \\
\hline Chemicals and allied & 0.24 & 0.79 & $\begin{array}{c}0.36 \\
(0.20)\end{array}$ \\
\hline Rubber and plastic products & 0.22 & 0.94 & $\begin{array}{c}0.29 \\
(0.16)\end{array}$ \\
\hline Lumber and wood products & 0.31 & 1.32 & $\begin{array}{c}0.09 \\
(0.09)\end{array}$ \\
\hline Pulp, paper, and allied product & 0.31 & 0.67 & $\begin{array}{c}0.35 \\
(0.19)\end{array}$ \\
\hline Metals and metal products & 0.31 & 0.72 & $\begin{array}{c}0.33 \\
(0.16)\end{array}$ \\
\hline Machinery and equipment & 0.30 & 0.44 & $\begin{array}{c}0.36 \\
(0.22)\end{array}$ \\
\hline Furniture and household & 0.20 & 0.35 & $\begin{array}{c}0.38 \\
(0.19)\end{array}$ \\
\hline Nonmetallic mineral & 0.31 & 0.47 & $\begin{array}{c}0.32 \\
(0.18)\end{array}$ \\
\hline Transportation equipment & 0.26 & 0.64 & $\begin{array}{c}0.15 \\
(0.11)\end{array}$ \\
\hline Miscellaneous products & 0.29 & 0.78 & $\begin{array}{c}0.18 \\
(0.12)\end{array}$ \\
\hline \hline
\end{tabular}

Note: In Column 4, the numbers in the parentheses are the standard deviation of the pairwise correlations across sectors.

Source: Author's calculation 


\section{Table 2}

\section{Contributions of Largest Principal Components to Total Variance}

\begin{tabular}{|l|c|c|c|c|c||}
\hline Commodity Groups & 1 & 2 & 3 & 4 & 5 \\
\hline \hline Farm products & 93.64 & 2.81 & 1.77 & 0.25 & 0.00 \\
\hline Processed foods and feeds & 71.30 & 0.27 & 0.77 & 2.77 & 0.35 \\
\hline Textile products and apparel & 9.53 & 7.55 & 24.04 & 3.20 & 0.36 \\
\hline Hides, skins, leather & 7.62 & 0.15 & 33.83 & 1.57 & 56.46 \\
\hline Fuels and related products & 1.94 & 92.95 & 2.79 & 1.94 & 0.34 \\
\hline Chemicals and allied & 7.35 & 19.21 & 9.43 & 29.44 & 3.17 \\
\hline Rubber and plastic products & 4.27 & 7.91 & 25.11 & 16.21 & 8.11 \\
\hline Lumber and wood products & 5.51 & 0.03 & 46.53 & 42.55 & 4.64 \\
\hline Pulp, paper, and allied product & 5.69 & 12.11 & 17.11 & 21.87 & 3.38 \\
\hline Metals and metal products & 4.30 & 14.67 & 16.72 & 11.83 & 3.64 \\
\hline Machinery and equipment & 2.85 & 11.45 & 10.70 & 25.97 & 5.20 \\
\hline Furniture and household & 5.38 & 11.33 & 14.14 & 17.53 & 3.45 \\
\hline Nonmetallic mineral & 2.60 & 17.10 & 5.85 & 13.25 & 2.74 \\
\hline Transportation equipment & 1.62 & 0.98 & 0.57 & 4.26 & 2.34 \\
\hline Miscellaneous products & 0.65 & 4.95 & 4.57 & 6.51 & 4.60 \\
\hline
\end{tabular}

Note: Monthly data for the period from January 1947 too January 2000.

Source: Author's calculation 


\section{Table 3}

Test-Statistics for Selecting the Number of Common Factor

\begin{tabular}{||l||c|c|c||}
\hline \hline Panel A: Goodness-of-fit Statistics - AIC and SC \\
\hline \hline Model & $\begin{array}{l}\text { Value of log- } \\
\text { likelihood function }\end{array}$ & AIC & SC \\
\hline \hline One-factor Model & -246.89 & 1.03 & 1.49 \\
\hline Two-factor Model & 32.21 & 0.33 & 0.76 \\
\hline Three-factor Model & 70.65 & 0.09 & 0.82 \\
\hline Four-factor Model & 99.75 & 0.06 & 0.91 \\
\hline Five-factor Model & 131.08 & 0.01 & 1.00 \\
\hline \hline Panel B: Sequential Likelihood Ratio Tests & $\begin{array}{l}\text { Estimated test } \\
\text { statistics }\end{array}$ & $\begin{array}{l}\text { Degrees of } \\
\text { freedom }\end{array}$ & $5 \%$ Critical value \\
\hline \hline Null Hypothesis & 558.2 & 18 & 28.87 \\
\hline One-factor vs. Two-factor & 76.88 & 18 & 28.87 \\
\hline Two-factor vs. Three-factor & 58.2 & 18 & 28.87 \\
\hline Three-factor vs. Four-factor & 62.7 & 18 & \\
\hline Four-factor vs. Five-factor & & & \\
\hline
\end{tabular}

Source: Author's calculation 


\section{Table 4}

Parameter Estimates: The State Equation

\begin{tabular}{||c|c||c||}
\hline AR Coefficients & One Factor Model & Two Factor Model \\
\hline$\varphi_{11}$ & $0.90^{* * *}$ & $0.93^{* * *}$ \\
& $(0.18)$ & $0.21)$ \\
\hline \multirow{2}{*}{$\varphi_{12}$} & 0.03 & 0.003 \\
& $(0.17)$ & $0.20)$ \\
\hline \multirow{2}{*}{$\varphi_{21}$} & & 0.012 \\
& & $(0.13)$ \\
\hline \multirow{2}{*}{$\varphi_{22}$} & & 0.007 \\
& & $(0.09)$ \\
\hline
\end{tabular}

Note: Standard errors (computed numerically) are in parentheses. *** denotes significance at the 1 percent level. 


\section{Table 5}

\section{Parameter Estimates: The Observation Equations}

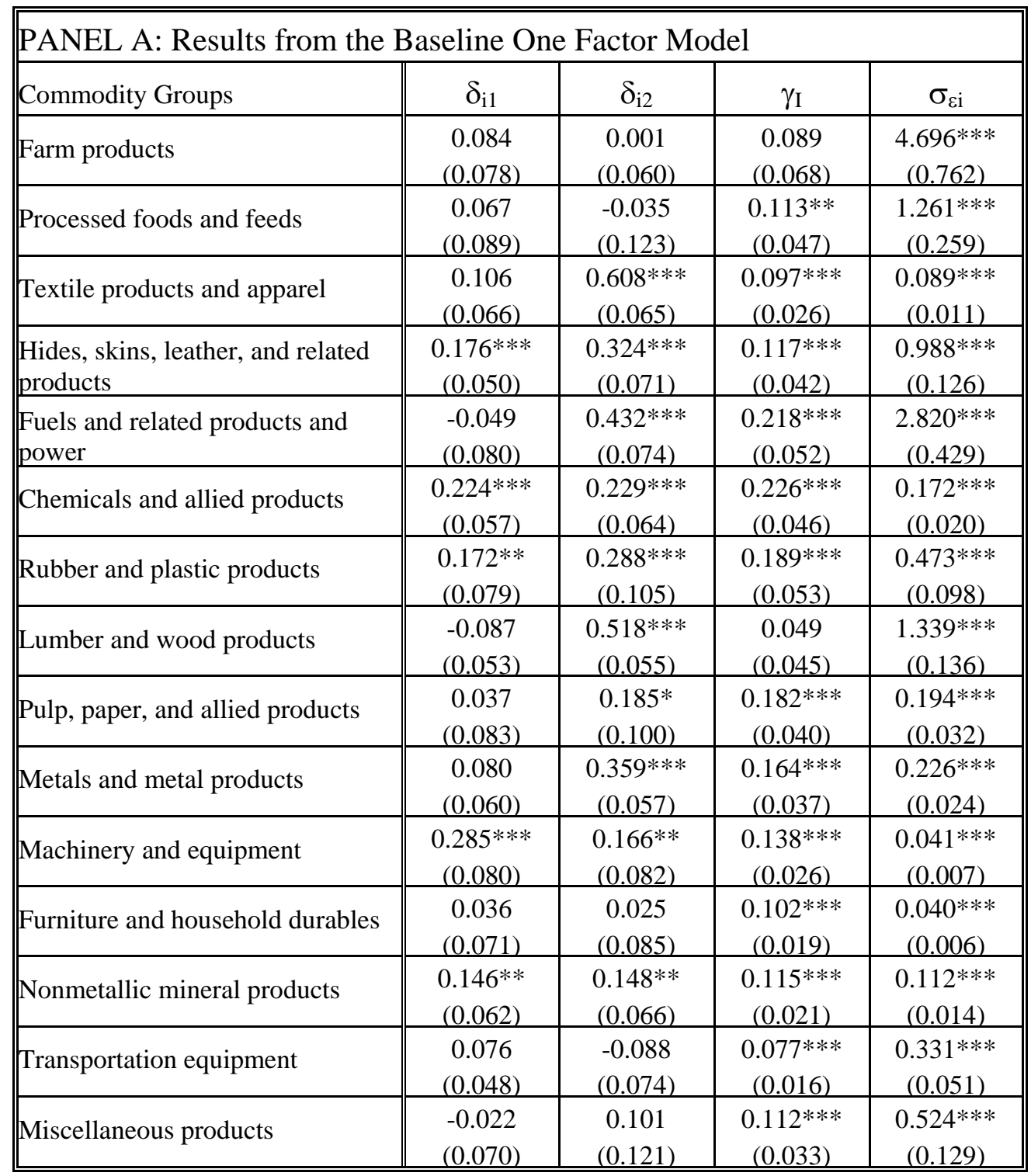

Note: Standard errors (computed numerically) are in parentheses. *** denotes significance at the 1 percent level; ** denotes significance at the 5 percent level and * denotes significance at the 10 percent level. 
Table 5 (Continued)

Parameter Estimates: The Observation Equations

\begin{tabular}{|c|c|c|c|c|c|}
\hline \multicolumn{6}{|c|}{ PANEL B: Results from Two Common Factor Model } \\
\hline Commodity Groups & $\delta_{\mathrm{i} 1}$ & $\delta_{\mathrm{i} 2}$ & $\gamma_{\mathrm{i} 1}$ & $\gamma_{\mathrm{i} 2}$ & $\sigma_{\varepsilon I}$ \\
\hline Farm products & $\begin{array}{c}0.027 \\
(0.049) \\
\end{array}$ & $\begin{array}{l}-0.038 \\
(0.042) \\
\end{array}$ & $\begin{array}{c}0.061 \\
(0.070)\end{array}$ & $\begin{array}{c}1.687^{* * *} \\
(0.232) \\
\end{array}$ & $\begin{array}{c}1.888^{* * *} \\
(0.173)\end{array}$ \\
\hline Processed foods and feeds & $\begin{array}{c}-0.746 * * * \\
(0.189)\end{array}$ & $\begin{array}{c}-0.799 * * * \\
(0.167)\end{array}$ & $\begin{array}{l}0.104^{* *} \\
(0.048)\end{array}$ & $\begin{array}{c}1.081^{* * *} \\
(0.123)\end{array}$ & $\begin{array}{c}0.018 \\
(0.022)\end{array}$ \\
\hline Textile products and apparel & $\begin{array}{c}0.105 \\
(0.068) \\
\end{array}$ & $\begin{array}{c}0.612 * * * \\
(0.066) \\
\end{array}$ & $\begin{array}{c}0.103^{* * *} \\
(0.036) \\
\end{array}$ & $\begin{array}{c}0.009 \\
(0.019) \\
\end{array}$ & $\begin{array}{c}0.089 * * * \\
(0.011)\end{array}$ \\
\hline $\begin{array}{l}\text { Hides, skins, leather, and } \\
\text { related products }\end{array}$ & $\begin{array}{c}0.176^{* * *} \\
(0.050)\end{array}$ & $\begin{array}{c}0.326^{* * *} \\
(0.071) \\
\end{array}$ & $\begin{array}{c}0.122^{* * *} \\
(0.047) \\
\end{array}$ & $\begin{array}{c}0.050 \\
(0.041)\end{array}$ & $\begin{array}{c}0.989 * * * \\
(0.126) \\
\end{array}$ \\
\hline $\begin{array}{l}\text { Fuels and related products } \\
\text { and power }\end{array}$ & $\begin{array}{l}-0.051 \\
(0.080)\end{array}$ & $\begin{array}{c}0.431 * * * \\
(0.074) \\
\end{array}$ & $\begin{array}{c}0.244^{* * *} \\
(0.048)\end{array}$ & $\begin{array}{l}-0.055 \\
(0.054)\end{array}$ & $\begin{array}{c}2.808^{* * *} \\
(0.430) \\
\end{array}$ \\
\hline Chemicals and allied products & $\begin{array}{c}0.221 * * * \\
(0.054)\end{array}$ & $\begin{array}{c}0.231 * * * \\
(0.063)\end{array}$ & $\begin{array}{c}0.245^{* * *} \\
(0.049)\end{array}$ & $\begin{array}{c}0.055 \\
(0.036)\end{array}$ & $\begin{array}{c}0.171^{* * *} \\
(0.019)\end{array}$ \\
\hline Rubber and plastic products & $\begin{array}{l}0.172^{* *} \\
(0.081) \\
\end{array}$ & $\begin{array}{c}0.292 * * * \\
(0.107) \\
\end{array}$ & $\begin{array}{c}0.206 * * * \\
(0.071)\end{array}$ & $\begin{array}{l}-0.015 \\
(0.037)\end{array}$ & $\begin{array}{c}0.473 * * * \\
(0.097)\end{array}$ \\
\hline Lumber and wood products & $\begin{array}{l}-0.088^{* *} \\
(0.052) \\
\end{array}$ & $\begin{array}{c}0.520 * * * \\
(0.054) \\
\end{array}$ & $\begin{array}{c}0.046 \\
(0.052) \\
\end{array}$ & $\begin{array}{c}0.068 \\
(0.063) \\
\end{array}$ & $\begin{array}{r}1.336 * * * \\
(0.134) \\
\end{array}$ \\
\hline $\begin{array}{l}\text { Pulp, paper, and allied } \\
\text { products }\end{array}$ & $\begin{array}{c}0.040 \\
(0.079) \\
\end{array}$ & $\begin{array}{l}0.199 * * \\
(0.097) \\
\end{array}$ & $\begin{array}{c}0.195^{* * * *} \\
(0.049)\end{array}$ & $\begin{array}{c}0.048 \\
(0.040)\end{array}$ & $\begin{array}{c}0.195^{* * *} \\
(0.032)\end{array}$ \\
\hline Metals and metal products & $\begin{array}{c}0.081 \\
(0.060) \\
\end{array}$ & $\begin{array}{c}0.361 * * * \\
(0.056)\end{array}$ & $\begin{array}{c}0.178^{* * * *} \\
(0.033)\end{array}$ & $\begin{array}{c}0.020 \\
(0.032)\end{array}$ & $\begin{array}{c}0.226^{* * *} \\
(0.024)\end{array}$ \\
\hline Machinery and equipment & $\begin{array}{c}0.279 * * * \\
0.080) \\
\end{array}$ & $\begin{array}{l}0.159 * \\
(0.083) \\
\end{array}$ & $\begin{array}{c}0.150^{* * *} \\
(0.031)\end{array}$ & $\begin{array}{c}0.014 \\
(0.015) \\
\end{array}$ & $\begin{array}{c}0.041^{* * *} \\
(0.007)\end{array}$ \\
\hline $\begin{array}{l}\text { Furniture and household } \\
\text { durables }\end{array}$ & $\begin{array}{c}0.035 \\
(0.072) \\
\end{array}$ & $\begin{array}{c}0.020 \\
(0.087)\end{array}$ & $\begin{array}{c}0.110^{* * *} \\
(0.024)\end{array}$ & $\begin{array}{c}0.014 \\
(0.015) \\
\end{array}$ & $\begin{array}{c}0.040^{* * *} \\
(0.006)\end{array}$ \\
\hline Nonmetallic mineral products & $\begin{array}{l}0.137 * * \\
(0.063) \\
\end{array}$ & $\begin{array}{l}0.137 * * \\
(0.068) \\
\end{array}$ & $\begin{array}{c}0.126^{* * *} \\
(0.022) \\
\end{array}$ & $\begin{array}{l}-0.009 \\
(0.023)\end{array}$ & $\begin{array}{c}0.111^{* * *} \\
(0.014) \\
\end{array}$ \\
\hline Transportation equipment & $\begin{array}{l}0.080^{*} \\
(0.047)\end{array}$ & $\begin{array}{l}-0.088 \\
(0.074) \\
\end{array}$ & $\begin{array}{c}0.083^{* * *} \\
(0.017) \\
\end{array}$ & $\begin{array}{c}0.034 \\
(0.027)\end{array}$ & $\begin{array}{c}0.330 * * * \\
(0.051) \\
\end{array}$ \\
\hline Miscellaneous products & $\begin{array}{l}-0.025 \\
(0.070)\end{array}$ & $\begin{array}{c}0.100 \\
(0.121) \\
\end{array}$ & $\begin{array}{c}0.122 * * * \\
(0.037) \\
\end{array}$ & $\begin{array}{l}-0.010 \\
(0.032) \\
\end{array}$ & $\begin{array}{c}0.523^{* * *} \\
(0.129) \\
\end{array}$ \\
\hline
\end{tabular}

Note: Standard errors (computed numerically) are in parentheses. $* * *$ denotes significance at the 1 percent level; ** denotes significance at the 5 percent level and * denotes significance at the 10 percent level. 


\section{Table 6}

\section{Forecast-Error Variance Decompositions of Price Changes}

\begin{tabular}{|c|c|c|c|c|c|}
\hline \multicolumn{6}{|c|}{ Panel A: Period 0 forecast-error variance decompositions } \\
\hline \multirow{3}{*}{ Commodity Groups } & \multicolumn{2}{|c|}{ One Common Factor Model } & \multicolumn{3}{|c|}{ Two Common Factor Model } \\
\hline & \multirow[t]{2}{*}{$\begin{array}{l}\% \text { contribution of } \\
\text { aggregate factor }\end{array}$} & \multirow[t]{2}{*}{$\begin{array}{l}\% \text { contribution of } \\
\text { sectoral factors }\end{array}$} & \multicolumn{2}{|c|}{$\begin{array}{l}\text { \% contribution of } \\
\text { aggregate factor }\end{array}$} & \multirow{2}{*}{$\begin{array}{c}\text { \% contribution } \\
\text { of sectoral } \\
\text { factors }\end{array}$} \\
\hline & & & Factor 1 & Factor 2 & \\
\hline Farm products & 0.17 & 99.83 & 0.08 & 60.08 & 39.85 \\
\hline Processed foods and feeds & 1.00 & 99.00 & 0.89 & 97.56 & 1.54 \\
\hline Textile products and apparel & 9.57 & 90.43 & 10.70 & 0.09 & 89.21 \\
\hline Hides, skins, leather, and & 1.36 & 98.64 & 1.48 & 0.24 & 98.28 \\
\hline Fuels and related products & 1.65 & 98.35 & 2.07 & 0.11 & 97.82 \\
\hline Chemicals and allied & 22.92 & 77.08 & 25.63 & 1.28 & 73.09 \\
\hline Rubber and plastic products & 7.01 & 92.99 & 8.21 & 0.04 & 91.75 \\
\hline Lumber and wood products & 0.18 & 99.82 & 0.16 & 0.34 & 99.50 \\
\hline Pulp, paper, and allied & 14.51 & 85.49 & 16.17 & 0.98 & 82.85 \\
\hline Metals and metal products & 10.59 & 89.41 & 12.21 & 0.15 & 87.64 \\
\hline Machinery and equipment & 31.86 & 68.14 & 35.43 & 0.32 & 64.25 \\
\hline Furniture and household & 20.58 & 79.42 & 23.19 & 0.39 & 76.42 \\
\hline Nonmetallic mineral & 10.47 & 89.53 & 12.59 & 0.06 & 87.35 \\
\hline Transportation equipment & 1.74 & 98.26 & 2.04 & 0.34 & 97.62 \\
\hline Miscellaneous products & 2.32 & 97.68 & 2.75 & 0.02 & 97.23 \\
\hline \multicolumn{6}{|c|}{ Panel B : 1 year ahead forecast error variance decompositions } \\
\hline Farm products & 1.00 & 99.00 & 0.46 & 59.83 & 39.71 \\
\hline Processed foods and feeds & 5.35 & 94.65 & 1.25 & 97.07 & 1.68 \\
\hline Textile products and apparel & 65.40 & 34.60 & 69.49 & 0.03 & 30.48 \\
\hline Hides, skins, leather, and & 13.07 & 86.93 & 14.79 & 0.20 & 85.01 \\
\hline Fuels and related products & 16.03 & 83.97 & 20.19 & 0.09 & 79.72 \\
\hline Chemicals and allied & 72.76 & 27.24 & 76.69 & 0.37 & 22.94 \\
\hline Rubber and plastic products & 43.29 & 56.71 & 49.10 & 0.02 & 50.88 \\
\hline Lumber and wood products & 2.12 & 97.88 & 2.00 & 0.33 & 97.67 \\
\hline Pulp, paper, and allied & 58.09 & 41.91 & 63.00 & 0.43 & 36.57 \\
\hline Metals and metal products & 57.13 & 42.87 & 62.43 & 0.06 & 37.51 \\
\hline Machinery and equipment & 78.38 & 21.62 & 81.61 & 0.08 & 18.31 \\
\hline Furniture and household & 61.78 & 38.22 & 66.35 & 0.17 & 33.48 \\
\hline Nonmetallic mineral & 47.40 & 52.60 & 53.47 & 0.03 & 46.50 \\
\hline Transportation equipment & 8.29 & 91.71 & 10.10 & 0.31 & 89.59 \\
\hline Miscellaneous products & 14.29 & 85.71 & 17.31 & 0.01 & 82.68 \\
\hline
\end{tabular}


Table 6 (continued)

\section{Forecast-Error Variance Decompositions of Price Changes}

\begin{tabular}{||l|c|c|c|c|c||}
\hline \multirow{2}{*}{ Panel C: 5 year ahead forecast-error variance decompositions } \\
\hline \multirow{3}{*}{ Commodity Groups } & \multicolumn{2}{|c|}{ One Common Factor Model } & \multicolumn{3}{|c||}{ Two Common Factor Model } \\
\cline { 2 - 5 } & $\begin{array}{c}\text { \% contribution of } \\
\text { aggregate factor }\end{array}$ & $\begin{array}{c}\text { \% contribution of } \\
\text { sectoral factors }\end{array}$ & $\begin{array}{c}\text { \% contribution of } \\
\text { aggregate factor }\end{array}$ & $\begin{array}{c}\text { \% contribution } \\
\text { of sectoral } \\
\text { factors }\end{array}$ \\
\cline { 3 - 6 } & & & Factor 1 & Factor 2 & 39.68 \\
\hline Farm products & 1.18 & 98.82 & 0.54 & 59.78 & 1.65 \\
\hline Processed foods and feeds & 6.25 & 93.75 & 1.36 & 96.99 & 20.95 \\
\hline Textile products and apparel & 75.59 & 24.41 & 79.03 & 0.02 & 81.47 \\
\hline Hides, skins, leather, and & 16.24 & 83.76 & 18.34 & 0.19 & 75.41 \\
\hline Fuels and related products & 19.67 & 80.33 & 24.51 & 0.08 & 19.20 \\
\hline Chemicals and allied & 76.97 & 23.03 & 80.49 & 0.31 & 44.87 \\
\hline Rubber and plastic products & 49.19 & 50.81 & 55.11 & 0.02 & 97.05 \\
\hline Lumber and wood products & 2.76 & 97.24 & 2.62 & 0.33 & 32.09 \\
\hline Pulp, paper, and allied & 62.77 & 37.23 & 67.53 & 0.38 & 31.86 \\
\hline Metals and metal products & 63.06 & 36.94 & 68.09 & 0.05 & 15.39 \\
\hline Machinery and equipment & 81.72 & 18.28 & 84.54 & 0.07 & 29.74 \\
\hline Furniture and household & 65.76 & 34.24 & 70.11 & 0.15 & 41.75 \\
\hline Nonmetallic mineral & 52.24 & 47.76 & 58.22 & 0.03 & 88.04 \\
\hline Transportation equipment & 9.59 & 90.41 & 11.66 & 0.30 & 79.91 \\
\hline Miscellaneous products & 16.65 & 83.35 & 20.08 & 0.01 & \\
\hline \hline
\end{tabular}




\section{Table 7}

Forecast-Error Variance Decompositions of Aggregate Price Changes at Various Time Horizons

\begin{tabular}{|c|c|c|c|c|c|}
\hline \multirow{3}{*}{ Months ahead } & \multicolumn{2}{|c|}{ One Common Factor Model } & \multicolumn{3}{|c|}{ Two Common Factor Model } \\
\hline & \multirow[t]{2}{*}{$\begin{array}{l}\% \text { contribution of } \\
\text { aggregate factor }\end{array}$} & \multirow[t]{2}{*}{$\begin{array}{l}\% \text { contribution of } \\
\text { sectoral factors }\end{array}$} & \multicolumn{2}{|c|}{$\begin{array}{c}\% \text { contribution of aggregate } \\
\text { factor }\end{array}$} & \multirow{2}{*}{$\begin{array}{l}\text { \% contribution } \\
\text { of sectoral } \\
\text { factors }\end{array}$} \\
\hline & & & Factor 1 & Factor 2 & \\
\hline \multicolumn{6}{|c|}{ PANEL A: All Commodity Groups } \\
\hline \begin{tabular}{|l|}
0 \\
\end{tabular} & 2.59 & 97.41 & 3.07 & 18.90 & 78.03 \\
\hline 1 & 4.56 & 95.44 & 5.55 & 18.33 & 76.12 \\
\hline 2 & 6.75 & 93.25 & 7.64 & 21.58 & 70.78 \\
\hline 3 & 8.94 & 91.06 & 9.82 & 23.73 & 66.45 \\
\hline 4 & 11.01 & 88.99 & 12.13 & 22.96 & 64.91 \\
\hline 5 & 12.85 & 87.15 & 13.65 & 25.11 & 61.24 \\
\hline 6 & 14.50 & 85.50 & 15.30 & 25.11 & 59.59 \\
\hline 7 & 15.91 & 84.09 & 16.71 & 25.12 & 58.17 \\
\hline 8 & 17.14 & 82.86 & 17.71 & 25.93 & 56.36 \\
\hline 9 & 18.18 & 81.82 & 18.77 & 25.66 & 55.57 \\
\hline 10 & 19.09 & 80.91 & 19.61 & 25.78 & 54.61 \\
\hline 11 & 19.86 & 80.14 & 20.26 & 26.03 & 53.71 \\
\hline 12 & 20.52 & 79.48 & 20.94 & 25.80 & 53.26 \\
\hline 24 & 23.93 & 76.07 & 24.13 & 25.58 & 50.29 \\
\hline 36 & 24.53 & 75.47 & 24.72 & 25.43 & 49.85 \\
\hline 48 & 24.63 & 75.37 & 24.82 & 25.40 & 49.78 \\
\hline 60 & 24.65 & 75.35 & 24.84 & 25.39 & 49.77 \\
\hline \multicolumn{6}{|c|}{ PANEL B: Excluding Food and Energy } \\
\hline \begin{tabular}{|l|}
0 \\
\end{tabular} & 10.15 & 89.85 & 11.64 & 0.49 & 87.87 \\
\hline 1 & 16.74 & 83.26 & 19.47 & 0.44 & 80.09 \\
\hline 2 & 23.39 & 76.61 & 27.01 & 0.39 & 72.60 \\
\hline 3 & 29.08 & 70.92 & 33.35 & 0.36 & 66.29 \\
\hline 4 & 33.78 & 66.22 & 38.45 & 0.33 & 61.22 \\
\hline 5 & 37.61 & 62.39 & 42.54 & 0.31 & 57.15 \\
\hline 6 & 40.71 & 59.29 & 45.79 & 0.29 & 53.92 \\
\hline 7 & 43.23 & 56.77 & 48.40 & 0.28 & 51.32 \\
\hline 8 & 45.29 & 54.71 & 50.51 & 0.26 & 49.23 \\
\hline 9 & 46.99 & 53.01 & 52.23 & 0.25 & 47.52 \\
\hline 10 & 48.39 & 51.61 & 53.65 & 0.25 & 46.10 \\
\hline 11 & 49.56 & 50.44 & 54.82 & 0.24 & 44.94 \\
\hline 12 & 50.54 & 49.46 & 55.79 & 0.24 & 43.97 \\
\hline 24 & 55.27 & 44.73 & 60.46 & 0.21 & 39.33 \\
\hline 36 & 56.05 & 43.95 & 61.22 & 0.21 & 38.57 \\
\hline 48 & 56.19 & 43.81 & 61.36 & 0.21 & 38.43 \\
\hline 60 & 60.70 & 39.30 & 61.38 & 0.21 & 38.41 \\
\hline
\end{tabular}




\section{Table 8}

Correlation between Estimated Common Factor and Changes in Money Stock, Government Expenditures and Unemployment Rate

\begin{tabular}{|c||c||c|c|}
\hline \multirow{2}{*}{} & $\begin{array}{c}\text { One factor } \\
\text { model }\end{array}$ & \multicolumn{2}{|c|}{ Two factor model } \\
\cline { 2 - 4 } & Common factor & First factor & Second factor \\
\hline \hline \multirow{2}{*}{$\Delta \mathrm{M} 1$} & $\begin{array}{c}0.076^{*} \\
(0.0450)\end{array}$ & $\begin{array}{c}0.071 \\
(0.0451)\end{array}$ & $\begin{array}{c}0.051 \\
(0.0451)\end{array}$ \\
\hline \multirow{2}{*}{$\Delta \mathrm{M} 2$} & 0.040 & 0.038 & 0.033 \\
& $(0.0451)$ & $(0.0451)$ & $(0.0452)$ \\
\hline \multirow{2}{*}{$\Delta \mathrm{M} 3$} & $0.18^{* * *}$ & $0.176^{* * *}$ & 0.037 \\
& $(0.0444)$ & $(0.0445)$ & $(0.0451)$ \\
\hline \multirow{2}{*}{$\Delta \mathrm{MB}$} & $0.119^{* * *}$ & $0.116^{* * *}$ & 0.024 \\
& $(0.0448)$ & $(0.0448)$ & $(0.0451)$ \\
\hline \multirow{2}{*}{$\Delta \mathrm{U}$} & $0.142^{* * *}$ & $0.150^{* * *}$ & -0.043 \\
& $(0.0447)$ & $(0.0447)$ & $(0.0451)$ \\
\hline \multirow{2}{*}{$\Delta \mathrm{G}$} & -0.048 & -0.041 & $-0.086 * *$ \\
& $(0.0451)$ & $(0.0451)$ & $(0.0450)$ \\
\hline
\end{tabular}

Note: The common factors are smoothed estimates using Kalman Filter. Monthly data for the sample period from January 1959 to January 2000. Standard errors are in parentheses. ${ }^{* * *}$ denotes significance at the 1 percent level; $* *$ denotes significance at the 5 percent level and * denotes significance at the 10 percent level. 


\section{Figure 1}

\section{Contributions of Common Factor: The Baseline Model}

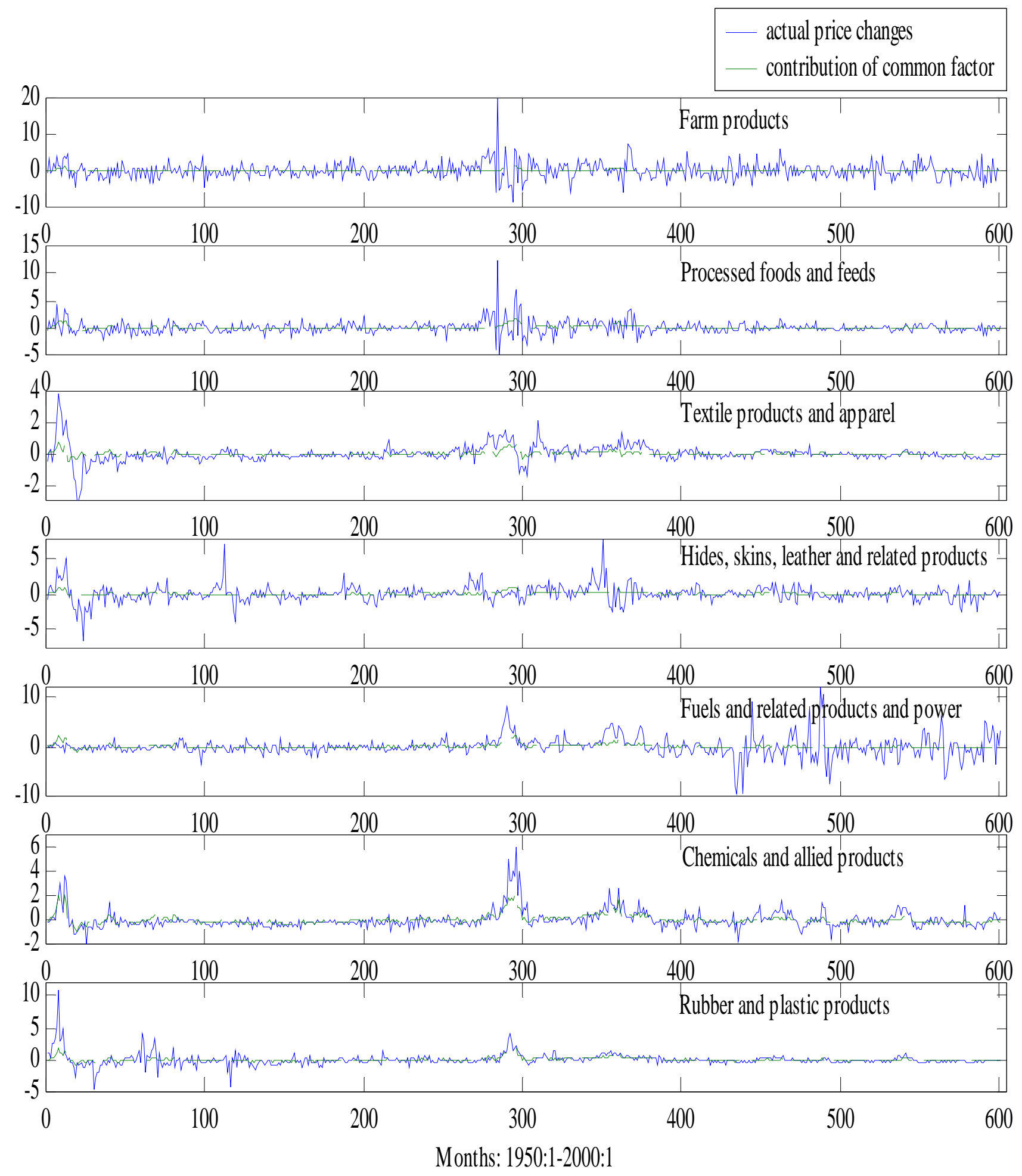


Figure 1 (contd)

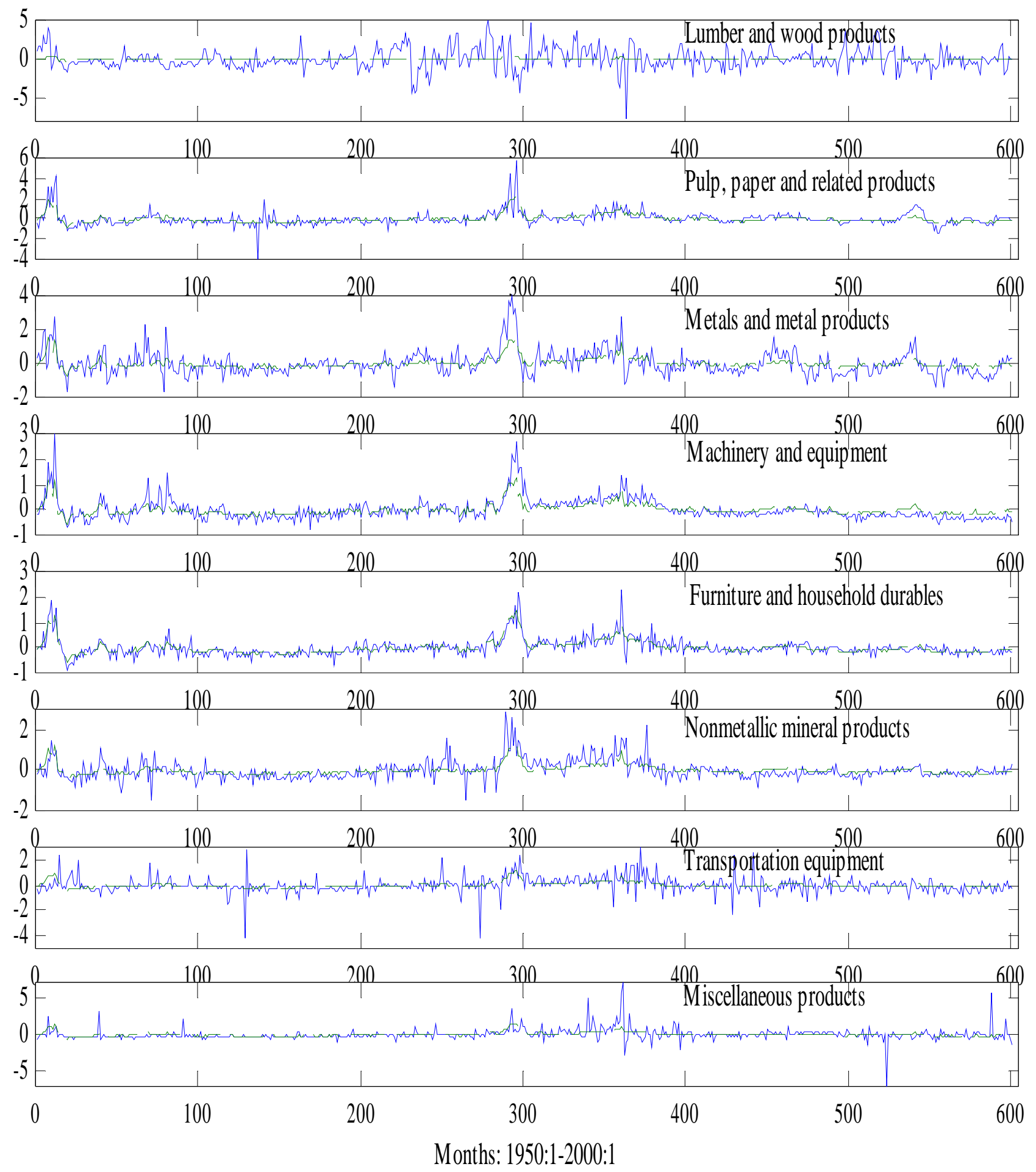


Figure 2

\section{Contributions of Common Factors: The Two Factor Model}

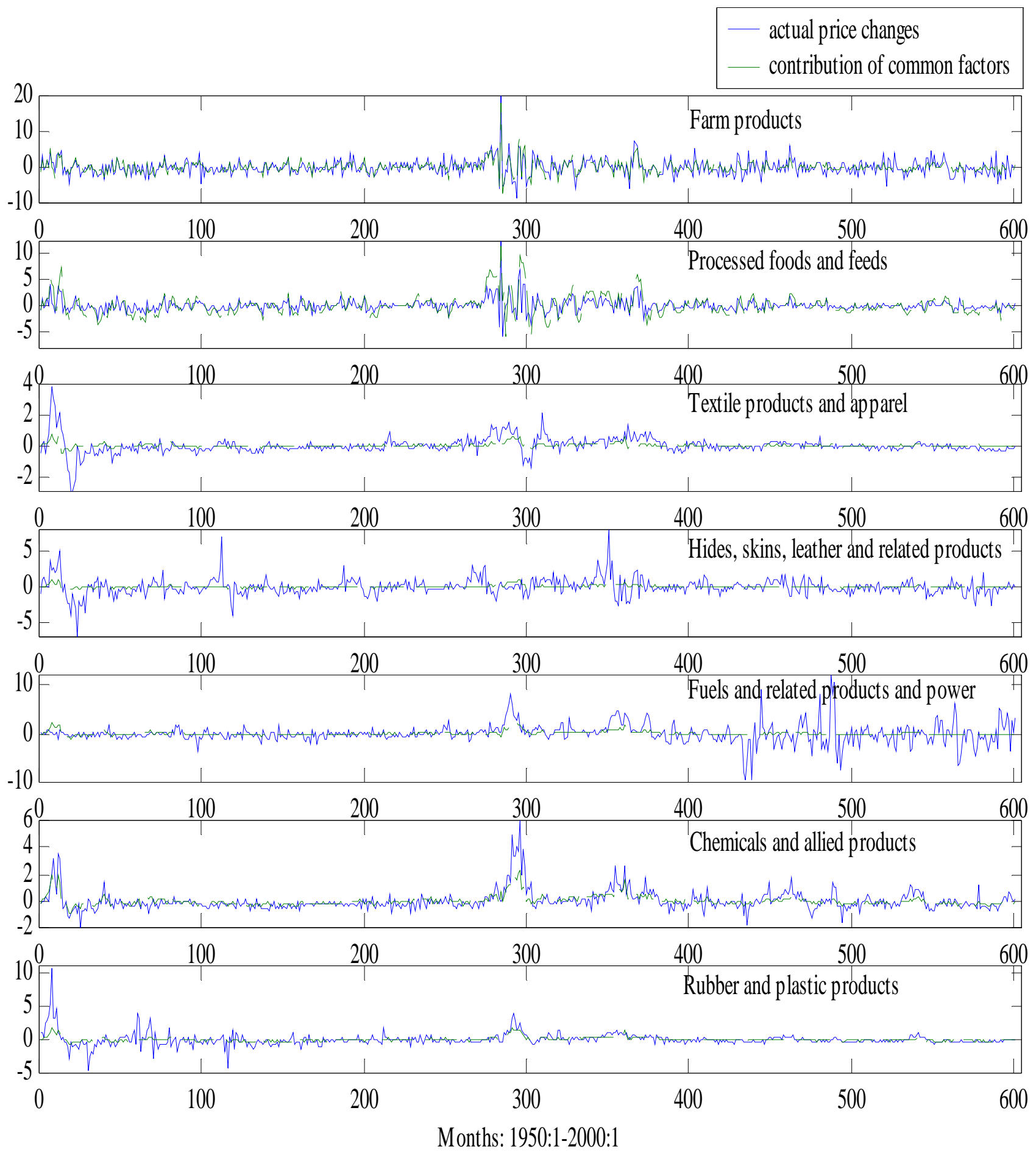




\section{Figure 2 (contd.)}

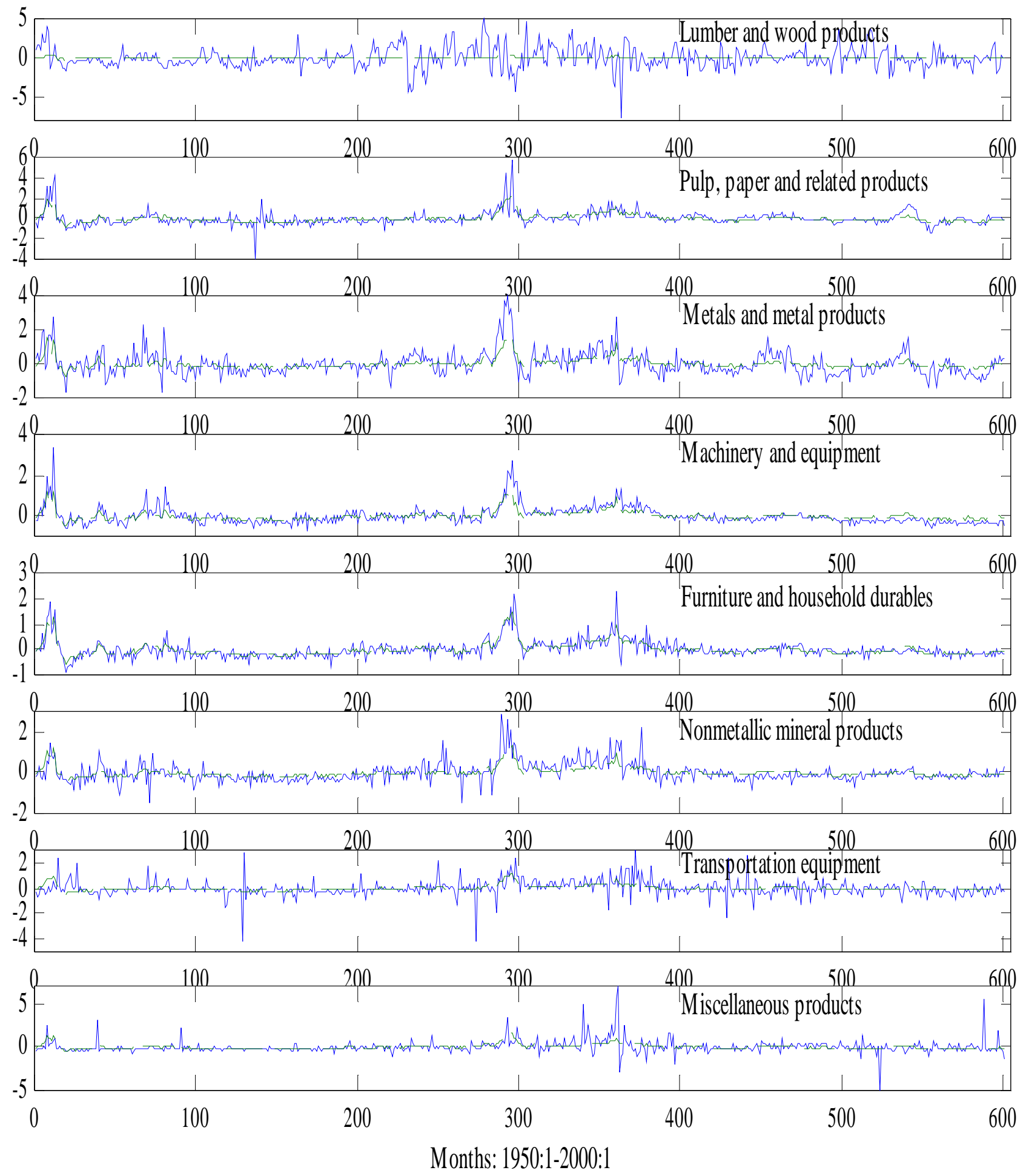




\section{References}

Balke, Nathan S. and Hiranya K. Nath (2001) Sectoral Price Changes and Output Growth: Demand and Supply in General Equilibrium, manuscript. Department of Economics, Southern Methodist University

Balke, Nathan S. and Mark A. Wynne (2000) An Equilibrium Analysis of Relative Price Changes and Aggregate Inflation, Journal of Monetary Economics, vol. 45, 269-292.

Ball, Lawrence and N. Gregory Mankiw (1995) Relative Price Changes as Aggregate Supply Shocks, Quarterly Journal of Economics, vol. 110, 161-193.

Barro, Robert J. (1976) Rational Expectations and the Role of Monetary Policy, Journal of Monetary Economics, vol. 2, 1-32.

Barsky, Robert B. and Lutz Kilian (2002) Do We Really Know that Oil Caused the Great Stagflation? A Monetary Alternative, NBER Macroeconomics Annual 2001, vol 16 (forthcoming)

Blinder, Alan (1982) The Anatomy of Double-Digit Inflation, in Inflation: Causes and Effects (Ed.) Robert E. Hall, Chicago, IL: University of Chicago Press.

Bryan, Michael F. and Stephen G. Cecchetti (1993) The Consumer Price Index as a Measure of Inflation, Federal Reserve Bank of Cleveland Economic Review, 15 - 23.

(Ed.) N. Gregory Mankiw, Chicago: University of Chicago Press for NBER.

Debelle, Guy and Owen Lamont (1997) Relative Price Variability and Inflation: Evidence from U.S. Cities, Journal of Political Economy, vol. 105 (1), 132-152.

Engle, Robert F. and Mark W. Watson (1983) Alternative Algorithms for the Estimation of Dynamic Factor, Mimic and Varying Coefficient Regression Models, Journal of Econometrics 23, 385-400.

Fischer, Stanley (1981) Relative Shocks, Relative price Variability and Inflation, Brookings Papers on Economic Activity (1981:2), 381-431.

Friedman, Milton (1975) Perspectives on Inflation, Newsweek, June 24.

----------, ------- (1987) The Supply of Money and Changes in Prices and Output, reprinted in The Essence of Friedman (Ed.) Kurt R. Leube Stanford, CA: Hoover Institution Press.

Graham, Frank (1930) Exchange, Prices, and Production in Hyperinflation: Germany 1920-23. Princeton, NJ: Princeton University Press. 
Hamilton, James D. (1994) Time Series Analysis, Princeton, NJ: Princeton University Press.

Harvey, Andrew C. (1989) Forecasting structural time series models and Kalman filter. Cambridge: Cambridge University Press.

Hercowitz, Zvi (1981) Money and the Dispersion of Relative Prices, Journal of Political Economy 89(21), 328-356.

Loungani, Prakash and Phillip Swagel (1995) Supply-side Sources of Inflation: Evidence from OECD Countries, International Finance Discussion Papers, No. 515, Board of Governors of the Federal Reserve System: Washington, D.C.

Lucas, Robert E., Jr. (1973) Some International Evidence on Output-Inflation Tradeoffs, American Economic Review, vol. 63, 326-34.

Mills, Frederick C. (1927) The Behavior of Prices. New York: National Bureau of Economic Research.

Norrbin, Stefan C. and Don E. Schlagenhauf (1990) Sources of Output Fluctuations in the United States During the Inter-war and Post-war Years, Journal of Economic Dynamics and Control, vol. 14, 523-551.

Singleton, Kenneth J. (1980) A Latent Time Series Model of the Cyclical Behavior of Interest Rates, International Economic Review, vol. 21, No.3, 559-575.

Stock, James H. and Mark W. Watson (1991) A probability model of the coincident economic indicators, in Leading economic indicators: New approaches and forecasting records (Ed.) Kajal Lahiri and Geoffrey H. Moore, Cambridge: Cambridge University Press.

Vining, Daniel R. and Thomas C. Elwertowski (1976) The Relationship between Relative Prices and the General Price Level, American Economic Review, vol.66 (4), 699-708. 